\title{
LITERATUR REVIEW PENGEMBANGAN MEDIA PEMBELAJARAN SAINS
}

\author{
Hikmah Fatimah ${ }^{1}$, Bramastia $^{2}$ \\ ${ }^{1}$ Program Studi S2 Pendidikan Sains, Fakultas Keguruuan dan Ilmu Pendidikan, Universitas Sebelas Maret \\ Surakarta, 57126, Indonesia \\ Email: ${ }^{1}$ hikmahfatimah2@gmail.com; ${ }^{2}$ bramastia@ staff.uns.ac.id
}

Diajukan: 15 Agustus 2021; Diterima: 2 September 2021; Diterbitkan: 30 Oktober 2021

\begin{abstract}
Abstrak: Pembelajaran sains membantu siswa menghubungkan fenomena yang terjadi dalam kehidupan dengan materi yang didapatkan disekolah. Konsep abstrak dalam sains menyebabkan siswa tidak dapat memahami materi dengan baik. Untuk itu, dibutuhkan media pembelajaran sains yang dapat membantu menyampaikan pesan dari sumber belajar kepada siswa. Media pembelajaran yang digunakan dalam pembelajaran meliputi media nyata dan digital. Desain penelitian berupa review terhadap jurnal yang terbit dalam sinta 6 hingga sinta 1 dalam kurun waktu 2016-2021. Hasil yang diperoleh bahwa terdapat 55 jurnal mengenai pengembangan media pembelajaran. Media pembelajaran cetak berupa kartu bergambar, scrapbook dan komik. Media pembelajaran digital berupa virtual lab, scholoogy, augmented reality, e-portofolio, animasi ,pageflip, edmodo, edumedia, appypie, mikroskop digital, power point dan flash. Berdasarkan analisis SWOT, terdapat kelemahan pada media pembelajaran sains yang telah dikembangkan seperti kurang mendukung apabila digunakan mandiri oleh siswa tanpa didampingi guru, membutuhkan teknologi lain untuk mengakses media tersebut dan dikembangkan pada materi yang fenomenanya sebenarnya mudah diamati oleh siswa dalam kehidupan sehari-hari.
\end{abstract}

Kata Kunci: Literature review, pengembangan media, pembelajaran sains

Abstract: Learning science helps students connect phenomena that occur in life with material obtained at school. Abstract concepts in science cause students to not be able to understand the material well. For this reason, science learning media is needed that can help convey messages from learning resources to students. Learning media used in learning include real and digital media. The research design is in the form of a review of journals published in Sinta 6 to Sinta 1 in the period 2016-2021. The results obtained are that there are 55 journals regarding the development of learning media. Printed learning media in the form of picture cards, scrapbooks and comics. Digital learning media in the form of virtual lab, scholoogy, augmented reality, eportfolio, animation, pageflip, edmodo, edumedia, appypie, digital microscope, power point and flash. Based on the SWOT analysis, there are weaknesses in the science learning media that have been developed such as being less supportive when used independently by students without being accompanied by a teacher, requiring other technology to access the media and being developed on material whose phenomena are actually easily observed by students in everyday life.

Keywords: Literature review, media development, science learning

\section{Pendahuluan}

Pembelajaran sains merupakan kegiatan menghubungkan konsep fisika, kimia dan biologi dengan fenomena yang terjadi di kehidupan siswa(Kemendikbud, 2018). Sebelum melaksanakan pembelajaran guru harus mempersiapkan perangkat, bahan ajar dan media yang digunakan dikelas. Dalam mengembangkan media pembelajaran, guru memanfaatkan keterbaharuan teknologi (Daston, L., \& Galison, 20017). Usia SMP merupakan periode peralihan operasional konkret menuju formal, sehingga masih terdapat batasan dalam membayangkan konsep yang abstrak(Ahmad, 2014). Pembelajaran sains mengandung banyak konsep abstrak yang sangat sulit diterima oleh siswa SMP. Apabila konsep tersebut tidak pernah dirasakan siswa, maka siswa semakin kesulitan membayangkan makna dari konsep tersebut. Hal ini menyebabkan tereduksinya pengetahuan sains siswa. Sehingga perlu adanya perbaikan pada perantara/ media(Ayu Permata Sari, Prima Aswirna, 2019). Untuk mengatasi hal ini, perlu adanya media interaktif yang mengandung teks, gambar (foto), film (video) dan lain sebagainya yang dapat mempermudah siswa dalam mencerna konsep abstrak. Penggunaan media merupakan suatu keharusan bagi guru karena dengan 
media, proses pembelajaran menjadi lebih efektif dan efisien. Selain itu media juga bisa menyeimbangkan kecepatan belajar yang berbeda-beda dari setiap siswa(Fajarwati, 2016). Tujuan umum dari media pembelajaran adalah sebagai perantara dan memudahkan dalam berkomunikasi (Saputra, 2017). Konsep asbtrak yang disampaikan melalui kata verbal menyebabkan siswa memahami pengetahuan dalam bentuk kata tanpa paham makna yang terkandung dalam kata tersebut. Maka diperlukan pengalaman siswa yang konkret agar tidak mengalami salah makna(Indriana, 2011). Pengalaman siswa dapat diperoleh melalui media pembelajaran. Media pembelajaran merupakan kebutuhan primer dalam kegiatan pembelajaran karena dapat digunakan untuk mengirimkan pesan, merangsang pikiran, perasaan, perhatian, dan keinginan siswa untuk belajar(Sumiati, 2008). Media pembelajaran sangat diperlukan pada waktu pengenalan konsep karena sebagai penghantar pesan.(N. Y. Sari \& Putra, 2018).

Pendidikan dan tekhnologi merupakan satu kesatuan. Pendidikan akan melahirkan tekhnologi, dan tekhnologi akan memajukan pendidikan(Priscylio, 2019). Revolusi industry 4.0 menuntut adanya penyetaraan tekhnologi dalam berbagai bidang. Selaras dengan perkembangan zaman, perkembangan tekhnologi juga merambah ke segala bidang, tak terkecuali bidang Pendidikan(R. U. Sari et al., 2020). Dalam melaksanakan pembelajaran sains guru lebih banyak mengembanngkan dua dan tiga dimensi. Seiring perkembangan teknologi, pengembangan media pembelajaran sains merambah pada pengembangan media digital. Media pembelajaran sangat membantu kegiatan belajar mulai dari sekolah dasar hingga perguruan tinggi. Guru dapat menggunakan atau mmebuat media yang sesuai dengan materi yang diajarkan, kondisi siswa dan kondisi sekolah. Media pembelajaran yang biasa digunakan oleh guru sains misalnya virtual lab, scholoogy, augmented reality, e-portofolio, animasi, pageflip, edmodo, edumedia, appypie, mikroskop digital, power point, kartu bergambar, flash, scrapbook dan komik,

Media pembelajaran cenderung dapat digunakan dalam berbagai strategi dan model pembelajaran dikelas. Media pembelajaran yang digunakan harus dapat membantu siswa dalam mencapai tujuan pembelajaran yang telah dikembangkan oleh guru misalnya meningkatkan literasi sains, berpikir kritis, berpikir kreatif dan inovatif. Media pembelajaran saat ini banyak dikembangkan oleh guru untuk dapat diakses oleh siswa diluar kelas. Sehingga sangat membantu kegiatan belajar mengajar di masa pandemic covid-19.

\section{Metode Penelitian}

Penelitian menggunakan analisis deskriptif dari data yang diperoleh. Penelitian menyajikan hasil penelusuran mengenai pengembangan media pembelajaran sains. Literature review dilakukan dengan fokus pada artikel original yang memuat abstrak, pendahuluan, metode, dan hasil. Pencarian artikel dilakukan pada database Sinta dengan kata kunci pengembangan media pembelajaran ipa. Kriteria data jurnal yang digunakan meliputi:

1) Jurnal terbit dalam rentang waktu 20162021

2) Data jurnal diperoleh melalui https://sinta.ristekbrin.go.id/

3) Data yang digunakan berupa jurnal yang terkait dengan pengembangan media pembelajaran sains

\section{Hasil Penelitian dan Pembahasan}

Pembelajaran sains dilaksanakan dengan menghubungkan konsep fisika, kimia dan biologi dengan fenomena dalam keseharian siswa(Yustiqvar, 2019). Namun terdapat beberapa konsep yang abstrak karena tidak dapat dihadirkan secara langsung didepan siswa saat pembelajaran sehingga siswa sulit untuk memahaminya. Untuk itu guru menggunakan media pembelajaran sebagai sarana komunikasi dengan siswa. Media pembelajaran berperan sebagai penghubung pesan dari sumber belajar dengan siswa. Saat menggunakan media pembelajaran, konsepkonsep abstrak dalam IPA dapat dipahami dengan baik oleh siswa(Rianti, 2013). Berdasarkan hasil analisis jurnal pada sinta 6 hingga sinta 1, terdapat 55 jurnal mengenai pengembangan media pembelajaran yang 
terbit dalam kurun waktu 2016-2021. Pengembangan media pembelajaran sains dilakukan dari jenjang SD hingga perguruan tinggi. Pengembangan media pembelajaran IPA berdasarkan jenjang dapat dilihat pada table dibawah ini :

Tabel 1 Jumlah pengembangan media berdasarkan jenjang

\begin{tabular}{lc}
\multicolumn{1}{c}{ Jenjang } & Jumlah \\
\hline SD & 7 \\
\hline SMP & 25 \\
\hline SMA & 13 \\
\hline Perguruan Tinggi & 10 \\
\hline
\end{tabular}

Dari tabel diatas dapat diketahui bahwa pengembangan media pembelajara paling banyak dilakukan pada jenjang SMP dan paling sedikit dikembangkan pada jenjang SD. Hal ini sesuai dengan teori Piaget, bahwa usia SMP merupakan peralihan antara tahap berpikir konkrit menuju tahap berpikir formal. Sehingga siswa membutuhkan stimulus untuk memperkuat ilustrasi yang dibayangkannya. Media pembelajaran yang dikembangkan berupa media nyata dan digital. Pengembangan media pembelajaran didasarkan pada kebutuhan materi, keadaan siswa dan keadaan lingkungan. Media pembelajaran dapat digunakan pada berbagai metode dan strategi pembelajaran. Media pembelajaran nyata meliputi buku, uriscrapbook, patung, torso, tanah yang secara langsung dapat di indera oleh siswa. Media berupa buku yang dikembangkan membuat pembelajaran berpusat kepada siswa, karena beruku berisi deskripsi lingkungan sekitar siswa yang dapat siswa identifikasi secara langsung(Herowati \& Azizah, 2020). Media pembelajaran uriscrapbook memberikan fasilitas pada siswa berupa ilustrasi materi yang menyerupai objek nyata(Rosyidah et al., 2019).

Sedangkan media pembelajaran digital memanfaatkan teknologi terbaru. Media pembelajaran digital dapat digunakan oleh guru membantu siswa memahami materi yang fenomenanya tidak dapat dibawa kedalam kelas. Misalnya terlalu besar, terlalu jauh atau diluar jangkauan. Pengembangan media pembelajaran disesuaikan dengan kebutuhan kelas, sehingga tujuan pengembangan media pembelajaran berbeda beda. Tujuan pengembangan media pembelajaran sains meliputi meningkatkan kemampuan kognitif, literasi sains,berpikir kritis, kemampuan proses, dan berpikir kreatif.

Pengembangan media digital dapat memanfatkan berbagai macam teknologi terbaru, misalnya menggunakan software adobeflash dan macromedia flash dengan bantuan LCD proyektor, $3 D$ pageflip professional, Edmodo, edu-media, yang dapat digunakan untuk menampilkan media didepan siswa. Selain itu, juga terdapat media berupa aplikasi berbasis android seperti SISTA, appypie, dan augmented reality.

Adobe flash dan Macromedia flash dapat membantu guru memvisualisasikan konsep dalam bentuk animasi yang lebih mudah ditangkap maknanya oleh siswa(Nur et al., 2017)(Astatin \& Nurcahyo, 2016). Animasi tersebut dapat diakses siswa melalui berbagai aplikasi. Saat menggunakan $3 D$ pageflip professional guru dapat membuat modul yang memberikan efek kertas yang dapat terbalik seperti buku sehingga lebih nyata(Diani et al., 2018). Selain itu, guru juga dapat memanfaatkan laman Edmodo, edumedia appypie, dan webblog yang dapat diisi materi, lembar kerja, dan soal-soal evaluasi(Aulia et al., 2019)(Firdawati et al., 2021)(Rohmawati et al., 2018). Laman Edmodo, edumedia appypie dan weblog dapat diakses oleh siswa dengan memanfaatkan jaringan internet. Pada laman tersebut siswa dapat melihat kumpulan materi yang telah dibagikan oleh guru. Selain itu, siswa juga dapat mengakses soal evaluasi yang dapat dihunungkan dengan laman lain seperti googleform. Aplikasi SISTA dapat digunakan guru untuk melaksanakan evaluasi terkait peningkatan pengetahuan siswa(Muhimmatin \& Ni, 2021). Augmented reality merupakan suatu media yang dibuat menggunakan software Vuforia dengan memanfaatkan kode seperti kode QR untuk membuka pesan berupa gambar yang mungkin tidak dapat dihadirkan dalam buku. Siswa dapat mengakses augmented relity dimanapun dan kapanpun jika siswa telah memiliki kode QR.

Selain itu, pengembangan media juga dilakukan menggunakan kombinasi media 
nyata dan digital. Kombinasi ini berupa powerpoint dan kartu bergambar. Media powerpoint menampilkan materi dan kartu bergambar menampilkan soal uraian pendek(Soramiranda et al., 2016).

Tren pengembangan media pembelajaran sains dari tahun ke tahun dapat dilihat pada grafik 1 .

Diagram 1 Tren pengembangan media pembelajaran sains

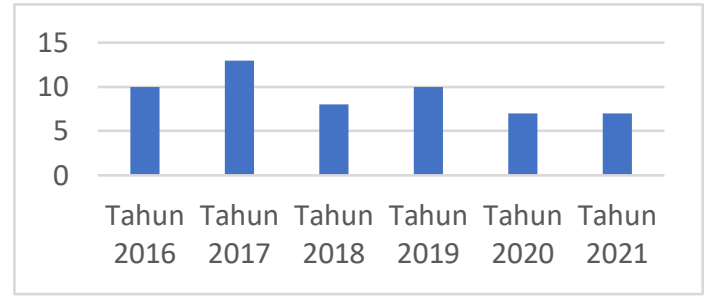

Dalam grafik 1. Dapat diketahui bahwa tren pengembangan media pembelajaran sains paling tinggi terjadi pada tahun 2017. Pada tahun 2017 pengembangan media pembelajaran sains dilaksanakn sebanyak 17 kali dan paling sedikit dilakukan pad atahun 2020 dan 2021 sebanyak 7 kali. Media yang dikembangkan berupa media nyata dan digital. Tren pengembangan jenis media dapat dilihat pada diagram 1.

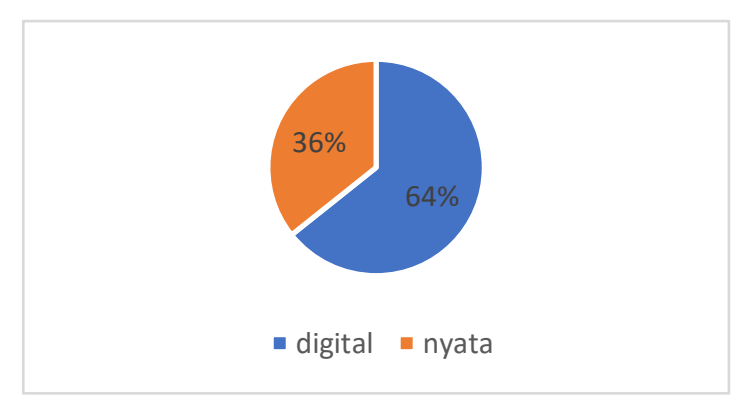

Diagram 2 Tren jenis media pembelajaran sains

Dalam diagram 1. Dapat diketahui bahwa tren pengembangan media pembelajaran sains paling banyak dilakukan dalam bentuk digital dengan presentase sebesar 64\%. Sedangkan pengembangan media pembelajaran sains dalam bentuk nyata sebesar $36 \%$. Pengembangan media pembelajaran sains digital dilakukan dengan memanfaatkan teknologi terbaru misalnya android,web, dan augmented reality. Persentase pengembangan media pembelajaran berdasarkan pada fokus kajian dapat dilihat dalam diagram 2

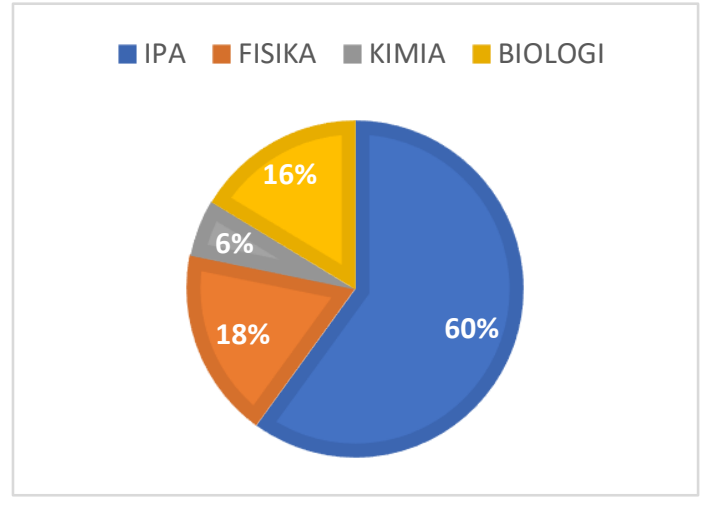

Diagram 3 Persentase pengembangan media pembelajaran berdasarkan fokus kajian

Berdasarkan diagram 2. Dapat diketahui bahwa persentase pengembangan media pembelajaran paling banyak pada pembelajaran sains sebesar $60 \%$, diikuti fisika sebesar $18 \%$, biologi sebesar $16 \%$ dan kimia sebesar $6 \%$. Media pembelajaran dikembangkan untuk menunjang kegiatan pembelajaran. Berdasarkan review artikel diatas, maka dapat dilakukan analisis SWOT pada media pembelajaran yang telah dikembangkan. SWOT sendiri merupakan analisis mengenai Kelebihan/Strengths, Kekurangan/Weaknesses, Peluang/Opportunitie $s$ dan Ancaman/Threats(Rochman, 2019). Analisis SWOT dapat digunakan untuk menganalisis factor yang mempengaruhi kelebihan, kekurangan, dan upaya yang dapat dilakukan untuk meningkatkan serta ancaman yang harus ditanggulangi dalam pengelolaan yang berkelanjutan(Fuad \& Susilo, 2021). Analisis SWOT dilakukan dengan tahap pengumpulan data(kondisi internal dan eksternal), analisis data dan pengambilan keputusan(Taruna, 2017). Berikut analisis SWOT bahan ajar yang telah dikembangkan selama ini:

1. Strength/kekuatan :

- Memabantu menyampaikan materi yang sulit dsainshami

- Dapat disesuaikan dengan kebutuhan kelas

- Dapat dsainskai dengan berbagai model dan strategi pembelajaran

- Berupa media nyata dan digital sehingga siswa lebih tertarik belajar

- Dapat digunakan untuk meningkatkan keterampilan tertentu 
- Pengetahuan sains siswa meningkat setelah menggunakan media yang telah dikembangkan

- Meningkatkan kemampuan memandang masalah dari perspektif lain

2. Weakness/ kelemahan:

- Kurang mendukung penggunaan mandiri tanpa guru

- Membutuhkan teknologi lain untuk mengakses,misalnya android,laptop dan internet

- Dikembangkan pada materi yang fenomenanya mudah diamati oleh siswa

3. Opportunity/peluang :

- Pembelajaran berpusat pada siswa

- Siswa lebih aktif dalam pembelajaran di kelas

- Guru dapat menggunakan model,metode dan strategi pembelajaran yang berbedabeda

- Siswa dapat mengaitkan fenomena dalam media dengan konsep abstrak dalam sains

- Siswa dapat mengaitkan fenomena dalam media dengan hukum-hukum sains

4. Threat/ ancaman :

- Siswa yang pasif tidak mendapatkan pengalaman belajar dan pemahaman materi yang baik

- Siswa yang pasif tidak dapat mengaitkan fenomena dalam media dengan konsep abstrak sains

- Keterbatasan teknologi android dan laptop oleh siswa

- Keterbatasan akses internet oleh siswa

Berdasarkan analisis SWOT diatas terdapat beberapa kelemahan dalam pengembangan media pembelajaran yang telah dilakukan selama ini, seperti kurang mendukung apabila digunakan mandiri oleh siswa tanpa didampingi guru, membutuhkan teknologi lain untuk mengakses media tersebut dan dikembangkan pada materi yang fenomenanya sebenarnya mudah diamati oleh siswa dalam kehidupan sehari-hari. Tujuan utama pengembangan media pembelajaran yaitu membantu siswa memahami materi yang dirasa sulit untuk dimengerti. Sebagian siswa memiliki keterbatasan dalam menangkap makna kata dalam buku, sehingga membutuhkan visualisasi. Berdasarkan teori kerucut pengalaman bahwa belajar menggunakan metode audiovisual dan dipraktekkan akan memberikan penyerapan materi sebesar 90\%(Dale, 1969). Untuk itu, pengembangan media pembelajaran sains yang lebih efektif adalah menggunakan multimedia interaktif.

Dalam menggunakan media pembelajaran dikelas, guru menyelipkan beberapa pertanyaan yang dapat menstimulasi siswa berpikir kritis. Sehingga siswa dapat mengembangkan keterampilan $4 \mathrm{C}$ yang meliputi Critical thinking, Creativity and Inovation, Collaboration, dan Communication (Charles Fadel, 2009). Penggunaan media pembelajaran sains di kelas dapat dsainsdukan dengan beberapa model pembelajaran yang disarankan oleh kurikulum 2013 seperti Inquiry Learning, Discovery Learning, Problem Based Learning, dan Project Based Learning(Markhus et al., 2019). Penggunaan media pembelajaran membantu mengurangi kesenjangan kecepatan belajar antar siswa dalam kelas sehingga dapat meningkatkan kualitas belajar siswa (Freeman et al., 2011). Selain itu penggunaan media dapat menekan angka kegagalan proses komunikasi dalam pembelajaran(Aripin \& Suryaningsih, 2019).

\section{Kesimpulan dan Rekomendasi}

Pada Jurnal Pengembangan Media Pembelajaran Sains yang dimuat dalam sinta 6 hingga sinta 1 dalam kurun tahun 2016-2021 sebanyak 55 jurnal. Media pembelajaran yang telah dikembangkan berupa media nyata dan digital. Media pembelajaran cetak berupa kartu bergambar, scrapbook dan komik. Media pembelajaran digital berupa virtual lab, scholoogy, augmented reality, e-portofolio, animasi ,pageflip, edmodo, edumedia, appypie, mikroskop digital, power point dan flash. Berdasarkan analisis SWOT yang telah dilakukan, teradat kelemahan pada media pembelajaran yang telah dikembangkan yaitu kurang mendukung apabila digunakan mandiri oleh siswa tanpa didampingi guru, membutuhkan teknologi lain untuk mengakses media tersebut dan dikembangkan pada materi yang fenomenanya sebenarnya mudah diamati oleh siswa dalam kehidupan sehari-hari. Untuk itu, sebaiknya dilakukan pembenahan dalam pengembangan media pembelajaran sains sehingga dapat membantu siswa memahami materi secara maksimal. 


\section{Daftar Pustaka}

Ahmad, S. (2014). Teori Belajar dan Pembelajaran. Prenadamedia Group.

Aripin, I., \& Suryaningsih, Y. (2019). Pengembangan Media Pembelajaran Biologi Menggunakan Teknologi Augmented Reality ( AR ) Berbasis Android pada Konsep Sistem Saraf. Jurnal Sainsmat, VIII(2), 47-57. http://ojs.unm.ac.id/index.php/sainsmat

Astatin, G. R., \& Nurcahyo, H. (2016). Pengembangan media pembelajaran biologi berbasis adobe flash untuk meningkatkan penguasaan kompetensi pada Kurikulum 2013. Jurnal Inovasi Pendidikan IPA, 2(2), 165. https://doi.org/10.21831/jipi.v2i2.10966

Aulia, L. N., Susilo, S., \& Subali, B. (2019). Upaya peningkatan kemandirian belajar siswa dengan model problem-based learning berbantuan media Edmodo. Jurnal Inovasi Pendidikan IPA, 5(1), 69-78. https://doi.org/10.21831/jipi.v5i1.18707

Ayu Permata Sari, Prima Aswirna, N. (2019). Pengembangan Multimedia Pembelajaran Fisika Menggunakan Swish Max 4.0 pada Materi Cahaya Kelas VIII Madrasah Tsanawiyah. Jurnal Penelitian Bidang Ipa Dan Pendidikan Ipa, 5(2), 824-834.

Charles Fadel, B. T. (2009). 21st Century Skills: Learning for life in Our Times. Jossey-Bass A Wiley Imprint.

Dale, E. (1969). Audio Visual Methods in Teaching. Holt, Rinehart and Winston Inc. The Dryden Press.

Daston, L., \& Galison, P. (20017). Objectivity. NY: Zone.

Diani, R., Hartati, N. S., \& Email, C. A. (2018). Flipbook berbasis literasi Islam: Pengembangan media pembelajaran fisika dengan 3D pageflip professional. Flipbook Berbasis Literasi Islam: Pengembangan Media Pembelajaran Fisika Dengan 3D Pageflip Professional, 4(2), 234-244. https://doi.org/10.21831/jipi.v4i2.20819

Fajarwati, S. (2016). MEDIA PEMBELAJARAN ANIMASI SWISHMAX SEBAGAI ALTERNATIF UNTUK SISWA SD YANG BERKESULITAN BELAJAR PADA MATERI BANGUN RUANG. 9(1), 38-51.

Firdawati, R., Maison, M., \& Nazarudin, N. (2021). Development of Mobile Learning Media on Newton's Laws Using the Appy Pie Application. Jurnal Penelitian Pendidikan IPA, 7(2), 202. https://doi.org/10.29303/jppipa.v7i2.599

Freeman, S., Haak, D., \& Wenderoth, M. P. (2011). Increased course structure improves performance in introductory biology. $C B E$
Life Sciences Education, 10(2), 175-186. https://doi.org/10.1187/cbe.10-08-0105

Fuad, A. J., \& Susilo, S. (2021). Analisis Penggunaan Media Online Dalam Pembelajaran di Masa Pandemi Covid-19 di MAN 1 Kota Kediri.

Herowati, H., \& Azizah, L. F. (2020). Ekplorasi Lingkungan Pesisir Kalianget Sebagai Media Pembelajaran Penunjang Pembelajaran Ipa Konstektual. LENSA (Lentera Sains): Jurnal Pendidikan IPA, IO(2), 137-156. https://doi.org/10.24929/lensa.v10i2.120

Indriana, D. (2011). Ragam alat bantu media pengajaran. DIVA Press.

Kemendikbud. (2018). Permendikbud Nomor 35 tahun 2018 Tentang Kurilkulum Sekolah Menengah Pertama/ Madrasah Tsanawiyah. Jakarta, 1-16.

Markhus, M., Harjono, A., Syukur, A., Bahri, S., \& Muntari. (2019). Analisis Rencana Pelaksanaan Pembelajaran (RPP) Terhadap Kesiapan Guru Sebagai "Role Model" Keterampilan Abad 21 Pada Pembelajaran IPA SMP. Jurnal Penelitian Pendidikan IPA ( JPPIPA ), 5(1), 66-72. https://doi.org/10.29303/jppipa.v5i1.171

Muhimmatin, I., \& Ni, I. (2021). Aplikasi mobile berbasis android sebagai media tes prior knowledge mahasiswa biologi Mobile App android-based as prior knowledge test media for biology undergraduate students. 7(1), 111.

Nur, I., Mukti, C., \& Nurcahyo, H. (2017). Developing Computer- Based Biology Learning Media to Improve the Students Learning Outcom. Jurnal Inovasi Pendidikan IPA, 3(2), 137-149.

Priscylio, G. (2019). Pengembangan Bahan Ajar Fisika Kontekstual Berbasis Inkuiri Terbimbing Pada Materi Rotasi. Journal of Teaching and Learning Physics, 4(1), 65-73. https://doi.org/10.15575/jotalp.v4i1.4094

Rianti, C. (2013). Pengembangan media pembelajaran biologi berbantuan komputer untuk meningkatkan hasil belajar peserta didik. Jurnal Pendidikan MIPA, 14(1), 6-10.

Rochman, I. (2019). Analisis SWOT dalam Lembaga Pendidikan (Studi Kasus di SMP Islam Yogyakarta). Al Iman: Jurnal Keislaman Dan Kemasyarakatan, 3(1), 3652.

http://ejournal.kopertais4.or.id/madura/index. php/aliman/article/view/3527

Rohmawati, E., Widodo, W., \& Agustini, R. (2018). Membangun Kemampuan Literasi Sains Siswa Melalui Pembelajaran Berkonteks Socio-Scientific Issues Berbantuan Media Weblog. Jurnal Penelitian 
Pendidikan IPA, 3(1), 8. https://doi.org/10.26740/jppipa.v3n1.p8-14

Rosyidah, N., Hidayat, J. N., \& Azizah, L. F. (2019). Uji Kelayakan Media Uriscrap (Uri Scrapbook) Menggunakan Model Pengembangan 4D. LENSA (Lentera Sains): Jurnal Pendidikan IPA, 9(1), 1-7. https://doi.org/10.24929/lensa.v1i1.43

Saputra, A. Y. (2017). Pengembangan Desain Media Pembelajaran Augmented Reality Untuk Komputer.

Sari, N. Y., \& Putra, F. G. (2018). Pengembangan Media Pembelajaran Berbantuan Software Swishmax pada Bahasan Bangun Ruang Sisi Datar. AKSIOMA : Jurnal Matematika Dan Pendidikan Matematika, 9(2), 72. https://doi.org/10.26877/aks.v9i2.2907

Sari, R. U., Farida, F., Andriani, S., \& Anggoro, B. S. (2020). Swishmax dalam Pengembangan
Media Pembelajaran Struktur Aljabar. Jurnal Pijar Mipa, 15(3), 280. https://doi.org/10.29303/jpm.v15i3.1548

Soramiranda, N., Ningsih, K., \& Panjaitan, R. G. P. (2016). Efektivitas Penggunaan Media Powerpoint Disertai Pada Materi Klasifikasi Makhluk Hidup. Jurnal Lentera Sains (Lensa), 6(2), 77-83.

Sumiati. (2008). Metode Pembelajaran. Wacana Prima.

Taruna, J. T. (2017). Analisis Organisasi dan PolaPola Pendidikan. SCU Knowledge Media.

Yustiqvar, M. (2019). ANALISIS PENGUASAAN KONSEP SISWA YANG BELAJAR KIMIA MENGGUNAKAN MULTIMEDIA INTERAKTIF BERBASIS GREEN CHEMISTRY. Journal Pijar MIPA, 14(3), 135-140. https://doi.org/10.29303/ jpm.v14i3.1299 